\title{
Proces przesylania danych diagnostycznych z systemu sterowania spalinowego pojazdu szynowego za pośrednictwem terminala satelitarnego
}

\begin{abstract}
$W$ niniejszym artykule przedstawiono uktad do testowania systemu transmisji satelitarnej zabudowanego na pojeździe szynowym, opisano tor $i$ mechanizm przesylania danych z lokomotywy do centrum diagnostycznego oraz kolejne etapy procesu pozyskiwania i analizy danych diagnostycznych.

Artykut powstat na podstawie prac prowadzonych $w$ ramach projektu badawczego „Zastosowanie satelitarnego systemu akwizycji danych do poligonowych badań spalinowych pojazdów szynowych" ( $\mathrm{nr} 4 \mathrm{T12D} 054$ 30) finansowanego przez Ministerstwo Nauki i Szkolnictwa Wyższego.
\end{abstract}

\section{Wstęp}

Transmisja satelitarna umożliwia przesyłanie danych diagnostycznych $\mathrm{z}$ pojazdu szynowego będącego w ruchu, niezależnie od jego usytuowania na szlaku kolejowym. W realizowanym projekcie badawczym zastosowano terminal satelitarny TT-3026L easyTrack duńskiej firmy Thrane \& Thrane A/S pracujący w standardzie Mini-C systemu satelitarnego INMARSAT. System ten jako jedyny, w chwili realizacji niniejszego projektu, świadczy usługi łączności z obiektami ruchomymi (statki, samoloty, pojazdy naziemne) [1].

Terminal zarejestrowano w Centrum Usług Satelitarnych TP SAT mieszczącym się w Psarach koło Kielc, które świadczy usługi w systemie INMARSAT. Centrum TP SAT jest operatorem dwóch lądowych stacji naziemnych LES (ang. „Land Earth Station") standardu INMARSAT-C. Stacje te uruchomiono 1 października 1997. Aktualnie współpracują one $\mathrm{z}$ następującymi satelitami INMARSAT trzeciej generacji: F1 w rejonie Oceanu Indyjskiego (IOR) oraz F2 we wschodnim rejonie Oceanu Atlantyckiego (AOR-E) [11].

Zastosowany terminal satelitarny umożliwia transmisję danych z szybkością $600 \mathrm{bit} / \mathrm{s}$ do oraz z pojazdu poruszającego się z prędkością nie przekraczającą $140 \mathrm{~km} / \mathrm{h}$. Do komunikacji z innymi urządzeniami (np. z komputerem lub sterownikiem PLC) terminal wyposażono w interfejs RS-232.

Terminal ten posiada również wbudowany 12 kanałowy odbiornik systemu GPS (ang. „Global Positioning System”), co umożliwia określenie pozycji, prędkości i kursu pojazdu oraz odbiór generowanego przez system GPS sygnału czasu wzorcowego UTC (ang. „Universal Coordinated Time”). Dane z systemu GPS odświeżane są co $1 \mathrm{~s}$.

\section{Układ do testowania transmisji satelitarnej za- budowany na pojeździe szynowym}

Testy transmisji danych diagnostycznych za pośrednictwem terminalu satelitarnego przeprowadzono $\mathrm{w}$ oparciu o układ przedstawiony na rys. 1. Układ ten zabudowano na 3-osiowej lokomotywie spalinowej typu 401Da (rys. 2), która wykorzystywana jest do realizacji manewrów na terenie IPS „TABOR” [2].

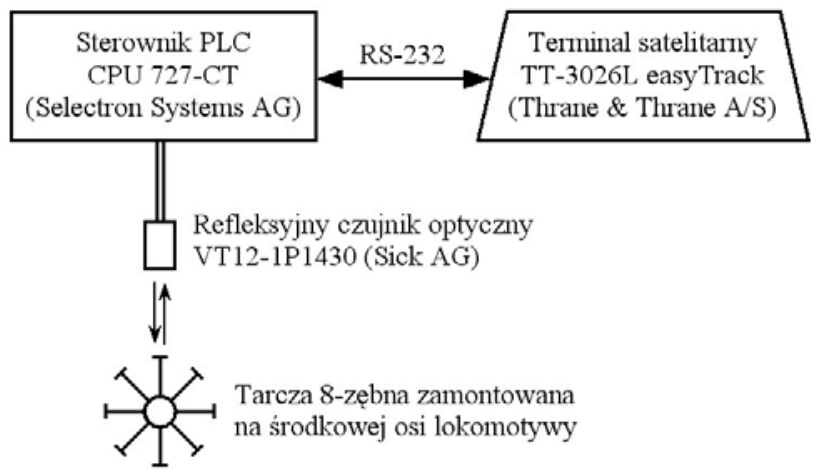

Rys. 1. Schemat układu do testowania transmisji satelitarnej [2]

Na środkowej osi lokomotywy zamontowano tarczę 8-zębną współpracującą z refleksyjnym czujnikiem optycznym (VT12-1P1430 firmy Sick AG). Sygnał wyjściowy z czujnika podawany jest na wejście licznikowe sterownika PLC (CPU 727-CT firmy Selectron Systems AG), który na jego podstawie wyznacza prędkość pojazdu. Sterownik PLC komunikuje się z terminalem satelitarnym (transmisja danych diagnostycznych) za pośrednictwem interfejsu RS-232. 


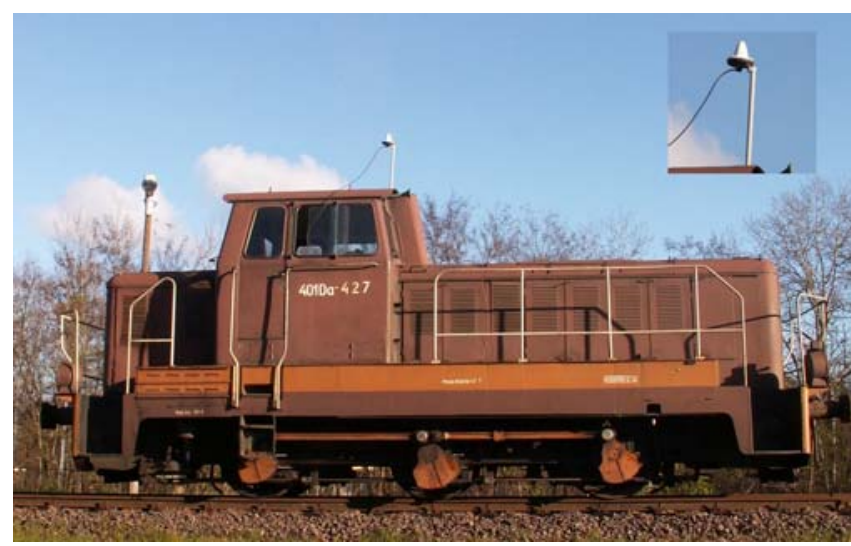

Rys. 2. Lokomotywa manewrowa 401Da z zainstalowanym terminalem satelitarnym TT-3026L [2]

3. Przebieg transmisji danych diagnostycznych $z$ systemu sterowania pojazdu szynowego do centrum diagnostycznego za pośrednictwem terminalu satelitarnego

Tor transmisji danych diagnostycznych $\mathrm{z}$ pojazdu szynowego do centrum diagnostycznego za pośrednictwem systemu satelitarnego INMARSAT przedstawiono na rys. 3 .

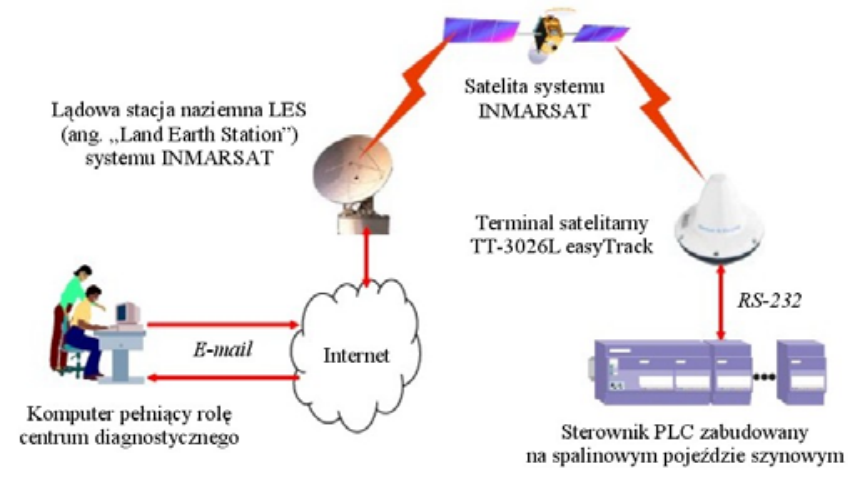

Rys. 3. Transmisja danych diagnostycznych z pojazdu szynowego do centrum diagnostycznego za pośrednictwem systemu satelitarnego INMARSAT wg [8]

W celu transmisji danych diagnostycznych $\mathrm{z}$ pojazdu do centrum akwizycji danych sterownik PLC przesyła do terminala satelitarnego następującą sekwencję [4]:

1. polecenie transferu danych $(\mathrm{TR}-$ Transfer Command) - polecenie utworzenia w pamięci Flash terminalu pliku o podanej nazwie i zapisu do niego określonej ilości znaków odebranych po łączu szeregowym:

tr $<$ Filename $>-$ b <data count $><\mathrm{CR}>$

gdzie:

$<$ Filename $>-$ nazwa pliku wg składni DOS

<data count >-ilość bajtów, która ma zostać zapisana w pliku

$<\mathrm{CR}>-$ znak powrotu karetki (ang. „Carriage Return" = \#13)
2. w projekcie: tr dane.dia -b $5050<\mathrm{CR}>$

3. zawartość pliku wg następującej struktury:

$<$ Address Prefix $><$ E-Mail

Address $><\mathrm{CR}\rangle\langle\mathrm{LF}\rangle$

$<$ Data Prefix $><\mathrm{CR}\rangle\langle\mathrm{LF}\rangle\langle$ User Data>

gdzie:

<Address Prefix>-dla stacji TP SAT

w Psarach jest to ciąg znaków „To:”

$<$ E-Mail Address $>$-adres poczty

elektronicznej, pod który ma zostać

dostarczona wiadomość e-mail zawierająca

przesyłane dane diagnostyczne

$<$ Data Prefix $>$-dla stacji TP SAT w

Psarach jest to ciąg znaków ,Stx:”

$<$ User Data $>$ - przesyłane dane

diagnostyczne

$<\mathrm{CR}>-$ znak powrotu karetki (ang. „Carriage

Return" = \#13)

$<L F>-$ znak końca wiersza (ang. ,Line

Feed" = \#10)

w projekcie:

To:elektrotechnika@tabor.com.p

$1<\mathrm{CR}>\langle\mathrm{LF}\rangle$

Stx: $<\mathrm{CR}><\mathrm{LF}>5011$ bajtów danych

diagnostycznych

4. polecenie wysłania utworzonego pliku (TX -

Transmit Command):

tx $<$ Filename $>-C<$ LES $>-\mathrm{s}$

$<$ Service $>-t<$ Destination $>$

$-1<$ Language $>-e$ SSAC No $>-v$ gdzie:

$<$ Filename $>-$ nazwa pliku do przesłania

$<$ LES $>$ - numer identyfikacyjny stacji LES;

w przypadku TP SAT w Psarach: „116” dla

stacji LES współpracującej z satelitą w regionie AOR-E oraz „316” dla stacji LES współpracującej z satelitą w regionie IOR

$<$ Service $>$ - dla trybu ,przechowaj i przekaż” (ang. ,store-and-forward”), w którym pracuje INMARSAT-C parametr ten musi być równy ,0"

$<$ Destination $>$ - parametr ten musi być równy ,6" - oznacza to wysyłanie wiadomości za pośrednictwem usługi „Special Access Code (SAC)” stacji LES <Language $>$ - rozmiar jednego bajtu danych: „7”- 8 bitów, „,0”- 7 bitów, „6" -5 bitów

Po otrzymaniu ze sterownika PLC polecenia transmisji, terminal satelitarny przesyła utworzony plik do satelity, który retransmituje go do lądowej stacji naziemnej. Stacja LES, po otrzymaniu pliku z terminalu satelitarnego, dokonuje jego translacji do postaci wiadomości e-mail i zapisuje w bazie danych 
wiadomości oczekujących na nadanie do odbiorcy. Czas oczekiwania wiadomości w kolejce zależy od aktualnego obciążenia stacji i może wahać się w zakresie od kilkunastu sekund do kilkunastu minut. Wiadomość e-mail, za pośrednictwem Internetu, przesyłana jest na konto pocztowe odbiorcy. Dane diagnostyczne przesyłane są w pliku /*.dat/ stanowiącym załącznik do wiadomości.

Przyjęto, że w jednej wiadomości przesyłanych będzie 100 ramek diagnostycznych o długości 50 znaków każda - w tym celu w pamięci sterownika PLC utworzono odpowiednią tablicę do przechowywania ich zawartości. Strukturę ramki zawierającej dane diagnostyczne przedstawiono $\mathrm{w}$ tab. 2.

Sterownik PLC w każdym cyklu pracy (co $100 \mathrm{~ms}$ ) w oparciu o sygnał wyjściowy z czujnika optycznego wyznacza prędkość środkowej osi pojaz$\mathrm{du}$, a następnie na podstawie otrzymanej wartości oraz zawartości poprzednich ramek generuje wartości poszczególnych prędkości (V1pom .. V4pom, V1śr .. V4śr), przyspieszeń (A1 .. A4, A1śr .. A4śr) oraz szarpnięć (Jerk1 .. Jerk4, Jerk1śr .. Jerk4śr) przesyłanych $\mathrm{w}$ ramce diagnostycznej [3]. Wartości poszczególnych danych diagnostycznych kodowane są na znaki ASCII, a otrzymana ramka zapisywana jest $\mathrm{w}$ pierwszym wierszu tablicy po uprzednim przesunięciu jej zawartości o jeden wiersz w dół. Zastosowany mechanizm sprawia, że w tablicy przechowywanych jest 100 ostatnich wygenerowanych przez sterownik ramek diagnostycznych.

Wysłanie pliku z danymi diagnostycznymi do centrum akwizycji danych następuje po zmianie stanu $\mathrm{z}$ niskiego na wysoki na jednym z wejść sterownika (umożliwiło to synchronizację przesyłu danych $\mathrm{z}$ rozruchem, jazdą i hamowaniem lokomotywy). Sterownik PLC przesyła wówczas do terminalu satelitarnego odpowiednie polecenia w celu uzyskania aktualnego czasu oraz pozycji geograficznej pojazdu (wg systemu GPS). Po uzyskaniu tych informacji sterownik przesyła do terminalu: polecenie transferu danych, nagłówek przedstawiony $\mathrm{w}$ tab. 1, zawartość kolejnych wierszy tablicy z ramkami diagnostycznymi (100 ostatnich ramek) oraz polecenie wysłania pliku.

Zakłada się, że docelowo uruchomienie transmisji będzie następowało albo po przesłaniu odpowiedniego rozkazu z centrum akwizycji danych (za pośrednictwem terminalu satelitarnego) albo po zaimplementowaniu w sterowniku algorytmu oceny stanu technicznego pojazdu i podejmowania decyzji o przesłaniu danych do centrum diagnostycznego.

\section{Struktura pliku /*.dat/ zawierającego zakodo- wane dane diagnostyczne}

Plik /*.dat/ z zakodowanymi danymi diagnostycznymi przesyłany jest jako załącznik do wiadomości e-mail wysyłanej przez terminal satelitarny do centrum akwizycji danych.
Plik ten składa się z 5011 znaków ASCII - pierwsze 11 znaków zawiera nagłówek wiadomości (tab. 1) natomiast kolejnych 5000 znaków to 100 ramek z zakodowanymi danymi diagnostycznymi (tab. 2).

Tab. 1. Nagłówek wiadomości

\begin{tabular}{|c|c|c|c|}
\hline $\begin{array}{l}\text { Znak } \\
\text { pliku }\end{array}$ & \multicolumn{2}{|c|}{ Interpretacja znaków } & Opis \\
\hline 1 & \multicolumn{2}{|c|}{ ID pakietu } & $\begin{array}{l}\text { identyfikator pa- } \\
\text { kietu }(0 \text {.. 255) }\end{array}$ \\
\hline 2 & \multicolumn{2}{|c|}{ ID wiadomości } & $\begin{array}{l}\text { identyfikator wia- } \\
\text { domości w pakie- } \\
\text { cie }(0 \text {. } 255)\end{array}$ \\
\hline 3 & \multicolumn{2}{|l|}{ godzina } & \multirow{3}{*}{ czas wg GPS } \\
\hline 4 & \multicolumn{2}{|l|}{ minuty } & \\
\hline 5 & \multicolumn{2}{|l|}{ sekundy } & \\
\hline 6 & stopnie & \multirow{3}{*}{$\begin{array}{l}\text { szerokość } \\
\text { geograficzna }\end{array}$} & \multirow{6}{*}{$\begin{array}{l}\text { pozycja geogra- } \\
\text { ficzna pojazdu wg } \\
\text { GPS }\end{array}$} \\
\hline 7 & minuty & & \\
\hline 8 & sekundy & & \\
\hline 9 & stopnie & \multirow{3}{*}{$\begin{array}{l}\text { długość geo- } \\
\text { graficzna }\end{array}$} & \\
\hline 10 & minuty & & \\
\hline 11 & sekundy & & \\
\hline
\end{tabular}

Tab. 2. Struktura ramki diagnostycznej $(n=0 . .99$ numer ramki)

\begin{tabular}{|c|c|c|c|c|}
\hline $\begin{array}{l}\text { Znak } \\
\text { pliku }\end{array}$ & $\begin{array}{c}\text { Znak } \\
\text { ram- } \\
\text { ki }\end{array}$ & \multicolumn{2}{|c|}{ Interpretacja znaków } & Opis \\
\hline $12+n$ & 1 & \multicolumn{2}{|l|}{ Licznik } & $\begin{array}{l}\text { zmienna } \\
\text { pomocnicza } \\
(0 . .255)\end{array}$ \\
\hline $13+n$ & 2 & V1pom_H & V1pom_M & \multirow{6}{*}{$\begin{array}{l}\text { zmierzone } \\
\text { prędkości } \\
\text { poszczególnyc } \\
\text { h osi pojazdu } \\
\text { pomnożone } \\
\text { przez } 100 \text { i } \\
\text { kodowane na } \\
12 \text { bitach }(1,5 \\
\text { znaku) }\end{array}$} \\
\hline $14+n$ & 3 & V1pom_L & V2pom_H & \\
\hline $15+n$ & 4 & V2pom_M & V2pom_L & \\
\hline $16+n$ & 5 & V3pom_H & V3pom_M & \\
\hline $17+n$ & 6 & V3pom_L & V4pom_H & \\
\hline $18+n$ & 7 & V4pom_M & V4pom_L & \\
\hline$\overline{19+n}$ & 8 & V1śr_H & V1śr_M & \multirow{6}{*}{$\begin{array}{l}\text { uśrednione } \\
\text { prędkości } \\
\text { poszczególnyc } \\
\text { h osi pojazdu } \\
\text { pomnożone } \\
\text { przez } 100 \text { i } \\
\text { kodowane na } \\
12 \text { bitach }(1,5 \\
\text { znaku) }\end{array}$} \\
\hline $20+n$ & 9 & V1śr_L & V2śr_H & \\
\hline $21+n$ & 10 & V2śr__M & V2śr_L & \\
\hline $22+n$ & 11 & V3śr_H & V3śr_M & \\
\hline $23+n$ & 12 & V3śr_L & V4śr_H & \\
\hline $24+n$ & 13 & V4śr_M & V4śr_L & \\
\hline $25+n$ & 14 & \multicolumn{2}{|l|}{$\mathrm{A} 1 \mathrm{H}$} & \multirow{8}{*}{$\begin{array}{l}\text { obliczone } \\
\text { przyspieszenia } \\
\text { poszczególnyc } \\
\text { h osi pojazdu } \\
\text { pomnożone } \\
\text { przez } 1000 \mathrm{i} \\
\text { kodowane na } 2 \\
\text { znakach }\end{array}$} \\
\hline $26+n$ & 15 & \multicolumn{2}{|l|}{ A1_L } & \\
\hline $27+n$ & 16 & \multicolumn{2}{|l|}{$\mathrm{A} 2 \mathrm{H}$} & \\
\hline $28+n$ & 17 & \multicolumn{2}{|l|}{ A2_L } & \\
\hline $29+n$ & 18 & \multicolumn{2}{|l|}{$\mathrm{A} 3 \mathrm{H}$} & \\
\hline $30+n$ & 19 & \multicolumn{2}{|l|}{ A3_L } & \\
\hline $31+n$ & 20 & \multicolumn{2}{|l|}{ A4_H } & \\
\hline $32+n$ & 21 & \multicolumn{2}{|l|}{ A4 L } & \\
\hline
\end{tabular}


Tab. 2. Struktura ramki diagnostycznej $(n=0 . .99-$ numer ramki) ciąg dalszy

\begin{tabular}{|c|c|c|c|}
\hline $33+n$ & 22 & A1śr_H & \multirow{8}{*}{$\begin{array}{l}\text { uśrednione } \\
\text { przyspieszenia } \\
\text { poszczególnyc } \\
\text { h osi pojazdu } \\
\text { pomnożone } \\
\text { przez } 1000 \text { i } \\
\text { kodowane na } 2 \\
\text { znakach }\end{array}$} \\
\hline $34+n$ & 23 & A1śr L & \\
\hline $35+n$ & 24 & A2śr $H$ & \\
\hline $36+n$ & 25 & A2śr_L & \\
\hline $37+n$ & 26 & A3śr $H$ & \\
\hline $38+n$ & 27 & A3śr_L & \\
\hline $39+n$ & 28 & A4śr $\mathrm{H}$ & \\
\hline $40+n$ & 29 & A4śr_L & \\
\hline $41+n$ & 30 & Jerk1_H & \multirow{8}{*}{$\begin{array}{l}\text { obliczone } \\
\text { szarpnięcia } \\
\text { poszczególnyc } \\
\text { h osi pojazdu } \\
\text { pomnożone } \\
\text { przez } 1000 \mathrm{i} \\
\text { kodowane na } 2 \\
\text { znakach }\end{array}$} \\
\hline $42+n$ & 31 & Jerk1_L & \\
\hline $43+n$ & 32 & Jerk2 H & \\
\hline $44+n$ & 33 & Jerk2 L & \\
\hline $45+n$ & 34 & Jerk3 H & \\
\hline $46+n$ & 35 & Jerk3_L & \\
\hline $47+n$ & 36 & Jerk4_H & \\
\hline $48+n$ & 37 & Jerk4 L & \\
\hline $49+n$ & 38 & Jerk1śr_H & \multirow{8}{*}{$\begin{array}{l}\text { uśrednione } \\
\text { szarpnięcia } \\
\text { poszczególnyc } \\
\text { h osi pojazdu } \\
\text { pomnożone } \\
\text { przez } 1000 \mathrm{i} \\
\text { kodowane na } 2 \\
\text { znakach }\end{array}$} \\
\hline $50+n$ & 39 & Jerk1śr_L & \\
\hline $51+n$ & 40 & Jerk2śr_H & \\
\hline $52+n$ & 41 & Jerk2śr_L & \\
\hline $53+n$ & 42 & Jerk3śr_H & \\
\hline $54+n$ & 43 & Jerk3śr_L & \\
\hline $55+n$ & 44 & Jerk4śr_H & \\
\hline $56+n$ & 45 & Jerk4śr_L & \\
\hline $57+n$ & 46 & Bajt1: bit7 .. bit0 & \multirow{3}{*}{$\begin{array}{l}24 \text { sygnały } \\
\text { binarne }\end{array}$} \\
\hline $58+n$ & 47 & Bajt2: bit7 .. bit0 & \\
\hline $59+n$ & 48 & Bajt3: bit7 .. bit0 & \\
\hline $60+n$ & 49 & CR (\#13) & \multirow{2}{*}{$\begin{array}{l}\text { znacznik } \\
\text { końca ramki }\end{array}$} \\
\hline $61+n$ & 50 & LF (\#10) & \\
\hline
\end{tabular}

\section{Proces analizy danych diagnostycznych}

Na rys. 4 przedstawiono kolejne kroki analizy danych diagnostycznych.

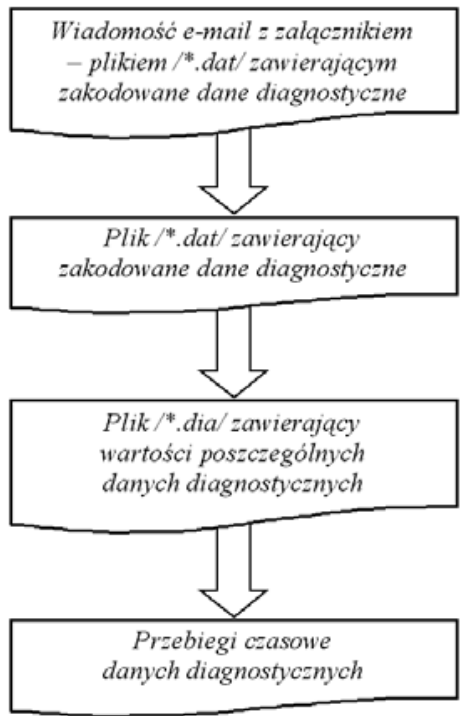

Program Microsoft Outlook Express:- zapis pliku załącznika $/ *$.dat/ na twardym dysku komputera

Program DiagSAT_Konwersja: - konwersja pliku załącznika /*.dat/ na plik tekstowy /*.dia/

Program Wykresy: - tworzenie wykresów

Rys. 4. Proces analizy danych diagnostycznych

\section{Program „DiagSAT_Konwersja”}

Program DiagSAT_Konwersja służy do konwersji plików /*.dat/ z zakodowanymi danymi diagnostycznymi na pliki tekstowe $/ *$.dia/ zawierające wartości poszczególnych danych. Program napisano w środowisku Borland Delphi 7.

\section{Uruchomienie programu i otwarcie pliku wejścio- wego /*.dat/}

Po uruchomieniu pliku DiagSAT Konwersja.exe na ekranie monitora pojawia się okno programu przedstawione na rys. 5. Po naciśnięciu przycisku Wybierz plik do konwersji wyświetlane jest okno otwarcia pliku wejściowego (rys. 6). Może zostać wybrany jedynie plik z rozszerzeniem $/ *$.dat/.

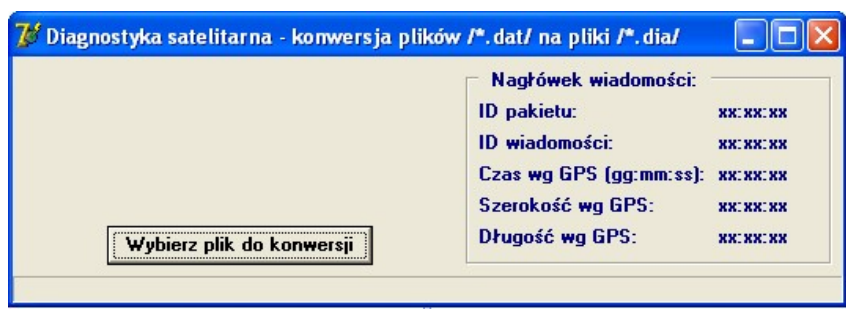

Rys. 5. Okno programu DiagSAT_Konwersja po jego uruchomieniu

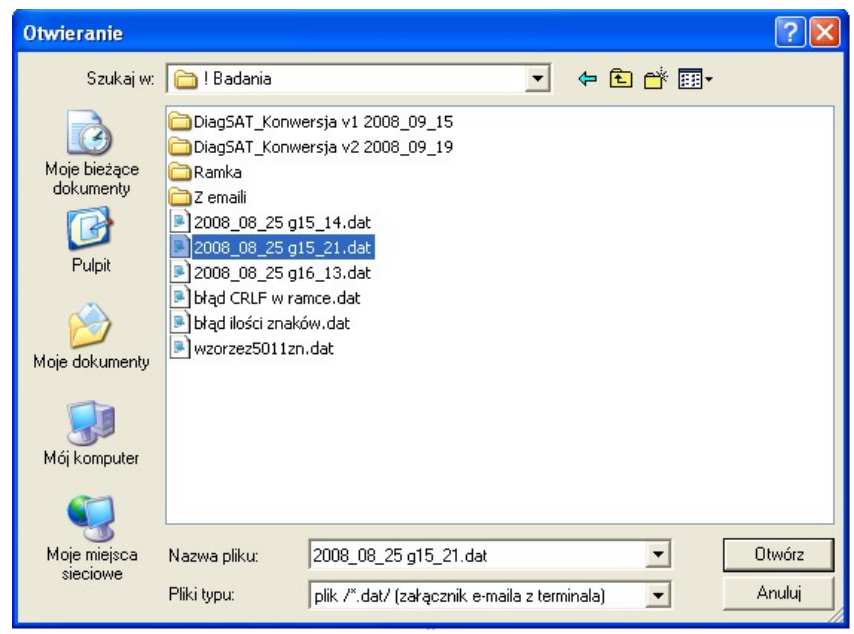

Rys. 6. Okno otwarcia pliku wejściowego /*.dat/

Konwersja pliku wejściowego /*.dat/ na plik wyjściowy /*.dia/

Po poprawnym otwarciu pliku wejściowego /*.dat/ zawierającego zakodowane dane diagnostyczne na dole okna programu, na pasku informacyjnym, prezentowana jest ścieżka dostępu do wybranego pliku.

Po otwarciu pliku wejściowego program sprawdza, czy ilość zapisanych w nim elementów odpowiada oczekiwanej ilości znaków wyznaczonej wg poniższego równania:

oczekiwana ilość znaków w pliku = ilość znaków nagłówka + rozmiar ramki * ilość ramek. Obecnie:

ilość znaków nagłówka $=11$ znaków rozmiar ramki $=50$ znaków ilość ramek $=100$ ramek, 
a więc:

oczekiwana ilość znaków w pliku $=11+50 *$ $100=5011$ znaków .

Jeżeli ilość znaków zapisanych w pliku różni się od oczekiwanej wartości, wówczas generowany jest komunikat przedstawiony na rys. 7, a wybrany plik wejściowy /*.dat/ nie jest dalej przetwarzany.

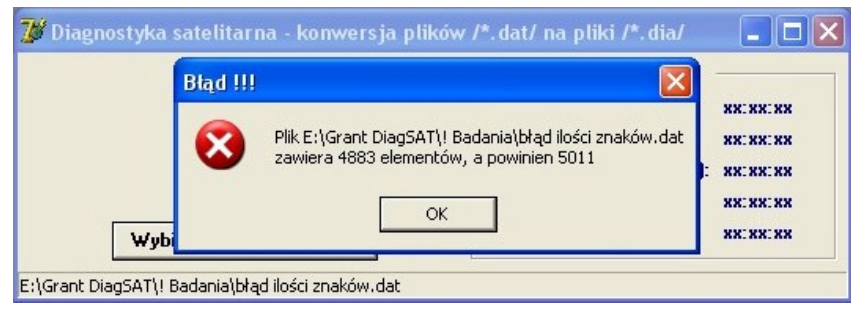

Rys. 7. Komunikat generowany w przypadku, gdy ilość znaków w pliku różni się od wartości oczekiwanej

Jeżeli ilość znaków zapisanych w pliku odpowiada wartości oczekiwanej, wówczas program rozpoczyna jego konwersję. Plik wyjściowy tworzony jest w tym samym folderze, w którym znajduje się plik wejściowy. Nazwa pliku wyjściowego tworzona jest poprzez dodanie rozszerzenia /*.dia/ do nazwy pliku wejściowego, przykładowo:

g15_14.dat

nazwa pliku wejściowego: 2008_08_25

nazwa pliku wyjściowego: 2008_08_25

g15_14.dat.dia.

Pierwsze 11 znaków pliku stanowi nagłówek wiadomości. Po konwersji nagłówka program wyświetla zawarte w nim informacje (rys. 8), tj.: identyfikator pakietu, identyfikator wiadomości oraz dane GPS pobrane przez sterownik PLC $\mathrm{z}$ terminalu satelitarnego: czas oraz pozycję geograficzną pojazdu. Odczytane dane zostają zapisane do nagłówka pliku wyjściowego /*.dia/. Struktura pliku wyjściowego została przedstawiona na rys. 12 .

Po przekonwertowaniu nagłówka program rozpoczyna konwersje ramek zawartych w pliku. Po odczytaniu ilości znaków odpowiadającej rozmiarowi ramki danych program sprawdza czy dwa ostatnie znaki to sekwencja CR LF - przyjęty znacznik końca ramki. Jeżeli ramka jest zakończona prawidłowo, wówczas następuje konwersja zawartych w niej znaków ASCII na wartości poszczególnych danych diagnostycznych. Dane otrzymane w wyniku konwersji pojedynczej ramki zostają zapisane jako kolejny wiersz pliku wyjściowego /*.dia/. W oknie programu prezentowany jest postęp procesu przetwarzania pliku wejściowego (rys. 8).

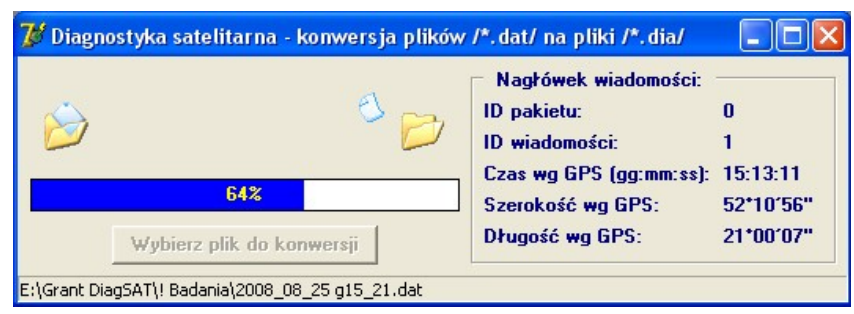

Rys. 8. Okno programu DiagSAT_Konwersja podczas konwersji pliku wejściowego

Jeżeli podczas przetwarzania pliku wejściowego program wykryje brak terminatora odczytanej ramki, wówczas generowany jest komunikat przedstawiony na rys. 9 i program przerywa procedure konwersji pliku wejściowego. W takim przypadku plik wyjściowy /*.dia/ zawiera jedynie ramki przekonwertowane do momentu wykrycia błędu.

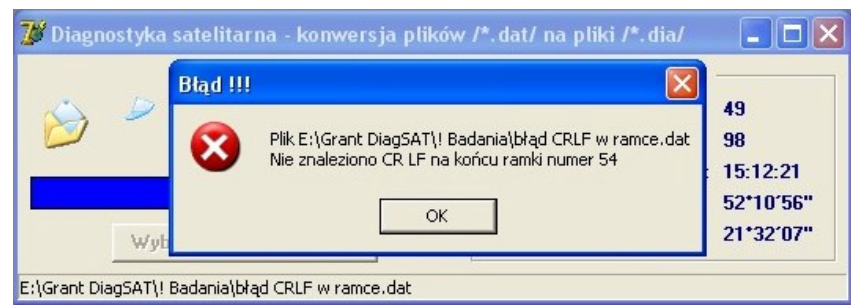

Rys. 9. Komunikat generowany w przypadku gdy odczytana ramka nie posiada terminatora $\mathrm{CR}$ LF

Po zakończeniu konwersji wszystkich ramek zawartych $\mathrm{w}$ pliku wejściowym generowany jest komunikat przedstawiony na rys. 10. Wygląd okna programu po zakończeniu konwersji pliku wejściowego przedstawiono na rys. 11.

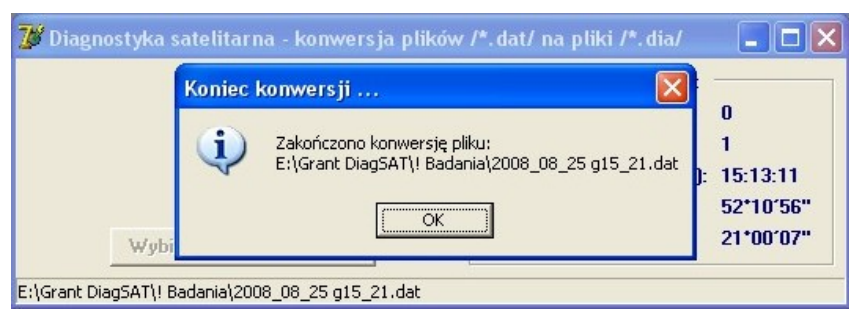

Rys. 10. Komunikat informujący o zakończeniu konwersji pliku wejściowego

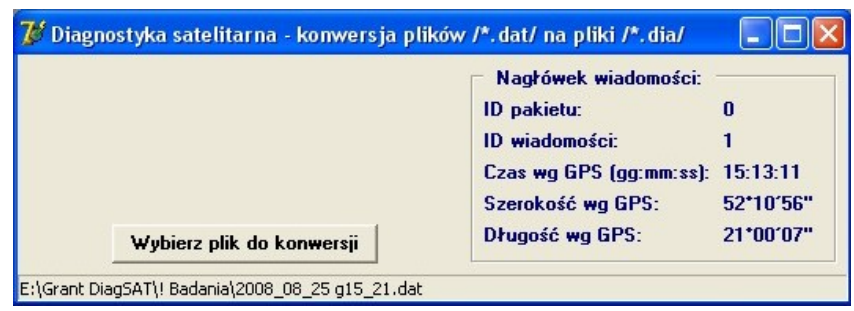

Rys. 11. Okno programu DiagSAT Konwersja po zakończeniu konwersji pliku wejściowego 


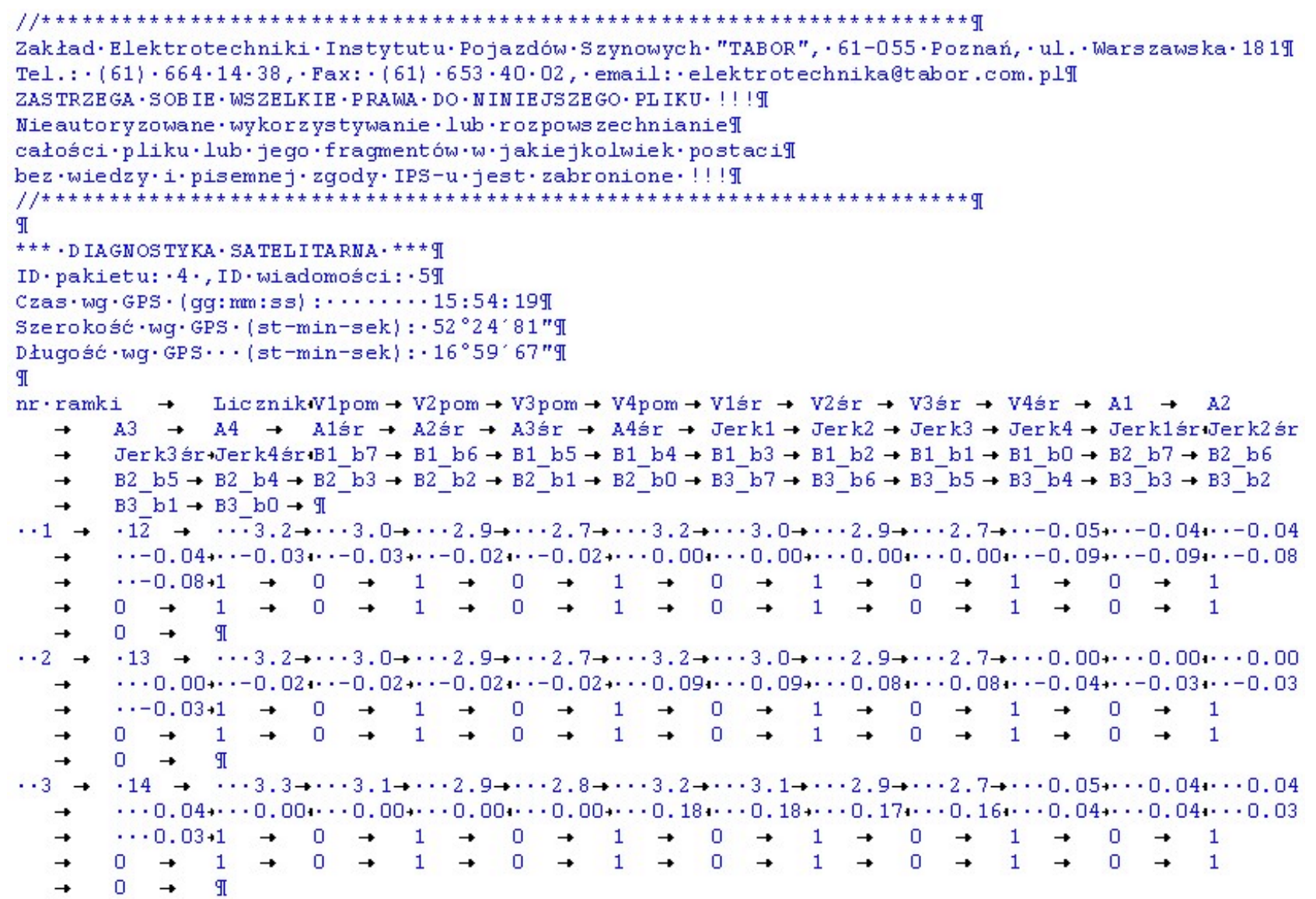

Rys. 12. Struktura pliku wyjściowego /*.dia/

\section{Struktura pliku /*.dia/ zawierającego dane diagno- styczne}

Na rys. 12 przedstawiono fragment pliku /*.dia/ (nagłówek pliku i pierwsze 3 ramki danych) tworzonego przez aplikację DiagSAT_Konwersja w wyniku przetwarzania pliku wejściowego $/ *$.dat/.

Plik wyjściowy /*.dia/ zawiera następujące informacje:

- wiersze od 1 do 8: sygnatura pliku

- wiersz 10: nazwa projektu

- wiersze od 11 do 14: nagłówek wiadomości

- wiersz 16: nazwy danych diagnostycznych zapisanych w pliku

- wiersze począwszy od 17: zawierają wartości poszczególnych danych diagnostycznych (jeden wiersz pliku odpowiada jednej ramce danych).

Do tworzenia wykresów $\mathrm{z}$ danych diagnostycznych zawartych w tym pliku można użyć aplikacji Wykresy [12] lub programów Microsoft Excel, OpenOffice Calc.

\section{Podsumowanie}

Zastosowanie terminalu satelitarnego zapewnia transmisję danych diagnostycznych $\mathrm{z}$ pojazdu szynowego będącego $\mathrm{w}$ ruchu niezależnie od jego usytuowania na szlaku kolejowym. Dodatkowo terminale łączności satelitarne zazwyczaj wyposażone są w moduł GPS (ang. „Global Positioning System"), co umożliwia wyznaczenie pozycji, prędkości i kursu pojazdu w wybranym układzie odniesienia (np. współrzędnych geograficznych) oraz odbiór generowanego przez system GPS sygnału czasu wzorcowego.

\section{Literatura}

[1] Haba M.: Możliwości wykorzystania przekazu satelitarnego $w$ diagnozowaniu stanu technicznego trakcyjnych pojazdów szynowych, Pojazdy Szynowe, Nr 4/2008.

[2] Kaczmarek A., Stypka M.: OR-9289 - Opis stanowiska badawczego oraz opis przeprowadzonych badan', Instytut Pojazdów Szynowych „TABOR”, Poznań 2008 (praca niepublikowana).

[3] Haba M., Barna G.: OR-9290 - Proces akwizycji danych diagnostycznych z systemu sterowania spalinowego pojazdu szynowego za pośrednictwem terminala satelitarnego, Instytut Pojazdów Szynowych „,TABOR”, Poznań 2008 (praca niepublikowana).

[4] Haba M., Stypka M.: OR-9114 - Programy do analizy $i$ prezentacji danych diagnostycznych, Instytut Pojazdów Szynowych „,TABOR”, Poznań 2007 (praca niepublikowana).

[5] Thrane \& Thrane A/S: TT-3026L/M easyTrack. Getting Started.

[6] Thrane \& Thrane A/S: TT-3026L/M/S easyTrack Transceiver. Installation Manual.

[7] Thrane \& Thrane A/S: TT-3026L/M/S easyTrack Transceiver. User/Operators Manual.

[8] Thrane \& Thrane A/S: Mini-C SCADA Integration Manual.

[9] www.thrane.com

[10] www.inmarsat.com

[11] www.psary.tpsa.pl

[12] Haba M.: Programy wspomagajace uruchamianie mikroprocesorowych systemów sterowania $w$ pojazdach szynowych, Pojazdy Szynowe, Nr 2/2007. 